\title{
EFFECT OF ARBUSCULAR MYCORRHIZAL FUNGI AND SOME PLANT GROWTH PROMOTING RHIZOBACTERIA IN CONTROLLING ROOT- KNOT NEMATODE (MELOIDOGYNE INCOGNITA) ON TOMATO UNDER GREENHOUSE CONDITIONS
}

\author{
Ghena M.E. Abdel Razek ${ }^{1 *}$ and Samah M. Abdelaziz ${ }^{2}$ \\ ${ }^{1}$ Deptartment of Plant Protection, Desert Research Center, El- \\ Matareya, Cairo, Egypt \\ ${ }^{2}$ Department of Fertility and Soil Microbiology, Desert Research \\ Center, El-Matareya, Cairo, Egypt \\ *E-mail: ghinamamdouh@yahoo.com
}

\begin{abstract}
greenhouse experiment was conducted to assess the influence
$A$ of some plant growth-promoting bacteria such as Azospirillum

lipoferum, Azotobacter chroorcoccum and Rhizobium leguminosarum alone or mixed with Arbuscular mycorrhizal fungi as bio fertilizer and bio control agents to enhance the growth of tomato (Lycopersicon esculentum cv. super strain P), suppress root knot nematode Meloidogyne incognita and microbial community composition. They improved plant growth through increased nutrient uptake in exchange for photosynthetic carbon from their host. Successful biocontrol has also in suppressed root knot nematode Meloidogyne incognita. In particular, combinations of AM fungi and PGPF may provide protection for plants at different times, under different conditions. Results indicated that all tested treatments significantly reduced root-knot nematode numbers and remarkable increase in the growth parameters as compared to the untreated inoculated plants. Both oxamyl and mixing of plant growth-promoting bacteria with arbascular mycorrhizae were the most effective treatments in decreasing the final nematode population in soil and roots, number of galls and rate of nematode buildup.
\end{abstract}

Keywords: Lycopersicon esculentum, Meloidogyne incognita, Azotobacter chroorcoccum, Azospirillum lipoferum, Rhizobium leguminosarum

The $1^{\text {st }}$ Conference of Plant Protection Science Applications for Sustainable Development of Desert Areas "Effect of Climate Change on Plant Pests and Biodiversity in Desert Environment" 19-20 October, 2019, Cairo-Egypt. 
Nematodes form a highly diverse group comprising free-living nematodes as well as plant and animal parasites that can be found worldwide in various habitats (Ferraz and Brown, 2002). Many species of plantparasitic nematodes (PPN) can act as pests on a wide range of important agricultural crops. They mostly live in the soil. Root-knot nematodes, which are considered to be the most damaging pests of agricultural crops worldwide (Jones et al., 2013 and Bartlem et al., 2014). The sedentary endoparasitic Meloidogyne spp. such as M. incognita and M. javanica, can result in complete crop losses in tobacco and tomato or sunflower and pepper, respectively (Wesemael et al., 2011). Tomato (Solanum lycopersicum) belongs to the Solanaceae family. Tomato is a rich source of micronutrients such as minerals, vitamins and antioxidants for a wellbalanced human diet. It also contains high levels of lycopene, an antioxidant that reduces the risks associated with several cancers and neurodegenerative disease (Giovannucci, 1999). There are many pests and diseases damaging both the quality and quantity of tomato production. Plant-parasitic nematodes are one of them. They represent an important constraint on the delivery of global food security. Damage caused by plant-parasitic nematodes has been estimated at US\$ 80 billion per year (Nicol et al., 2011).

The use of nematicides is being limited, given the increasing concern for human health as well as the environment, which has led to their ban. Alternative nematicides are being sought (Oka and Mizukubo, 2009 and Wesemael et al., 2011). Scientists are also looking for other nematode management strategies that fit into the recently launched framework of the Integrated Pest Management (IPM) directive of the European Union (EU directive 2009/128/EC), stating that member states have to implement IPM from 2014 onward, with the aim to reduce pesticide use and to promote nonchemical management practices as much as possible. One of the proposed environmentally friendly options to manage PPN is the use of biological control organisms, such as arbuscular mycorrhizal fungi (AMF).

Arbuscular mycorrhizal fungi are obligate root symbionts, estimated to colonize more than $80 \%$ of all land plant species. They improve plant growth through increased nutrient uptake in exchange for photosynthetic carbon from their host (Smith et al., 2010). Also, they can alleviate plant stress caused by abiotic as well as biotic factors, including PPN (Gianinazzi et al., 2010; Singh et al., 2011 and Vos et al., 2012) The biocontrol effect of AMF has been observed in a wide range of plant species and against many pathogens, most of them soil-borne fungal pathogens causing root rot or wilting, though successful biocontrol has also been observed against aboveground pathogens such as Alternaria solani in tomato (Harrier and Watson, 2004; Whipps, 2004; Fritz et al., 2006; Pozo and Azcón-Aguilar, 2007 and Jung et al., 2012). Both necrotrophic and biotrophic pathogens

Egyptian J. Desert Res., 69, Special Issue, 131-150 (2019) 
have been reported to be suppressed by AMF, either directly or indirectly (Veresoglou and Rillig, 2012).

Plant growth-promoting rhizobacteria (PGPR) are free living and may impart beneficial effects on plants. PGPRs are a specific group of soil bacteria that aggressively colonize the rhizosphere and rhizoplane, and substantially improve plant growth and productivity through various mechanisms like N2 fixation, solubilization of minerals phosphates and other essential nutrients, and biological control agents of phytopathogenic microorganisms (Bhattacharya and Jha, 2012). In addition, PGPR can protect plants from detrimental effects of environmental stress like flooding, drought, salinity and heavy metals

Authors have frequently described as PGPRs certain strains of Pseudomonas, Bacillus, Azospirillum, Azotobacter, Enterobacter and Serratia (Kloepper and Beauchamp 1992), since they share common habitats, i.e., the root surface, and common functions, the AMF and PGPR have to interact during their processes of root colonization or functioning as root-associated microorganisms. Soil microorganisms, particularly PGPR, can influence AM formation and function and consequently, mycorrhizae can affect PGPR populations in the rhizosphere (Barea, 2000) Relationships between both types of microbes are under high specificity rules (Azcón, 1989).

Recently, numerous researches have focused on biological control agents with the objective of controlling the plant parasitic nematodes and to overcome the nematode damage by using mycorrhizal fungus (Duponnois and Plenchette, 2003 and Serfoji et al., 2010) or bacteria such as Azospirillum brasilense (Shamseldin et al., 2010), Rhizobium leguminosarum (Ashoub and Amara, 2010) and Azotobacter chroorcoccum (Siddiqui and Futai, 2009).

\section{MATERIALS AND METHODS}

The experiment was conducted at the experimental greenhouse of Nematodes Research Department, Plant Protection Dept., Desert Research Center (DRC), El-Matareya, Cairo, Egypt and at the Experimental Laboratory of Fertility and soil Microbiology Dep. Desert Research Center DRC), El-Matareya, Cairo, Egypt

\section{Nematode Stock Culture and Propagation}

To initiate and propagate pure stock culture of the root -knot nematode, Meloidogyne incognita (Kofoid and White) Chitwood, galled roots of highly infected eggplants were collected, single egg-masse was used to inoculate eggplants grown under greenhouse conditions. The identification of females perennial pattern was done according to Taylor et

Egyptian J. Desert Res., 69, Special Issue, 131-150 (2019) 
al. (1955). Two months later re-inoculation on new eggplants continuously was done for preparing pure egg mass culture of Meloidogyne incognita.

\section{Arbuscular Mycorrhizal Fungus}

The spores of VAM were collected from different Egyptian governorates by the wet sieving technique, described by Gerdemann and Nicolson (1963). The collected VA Mycorrbizal spores were propagated in soil and the roots of barley plants were infected with VAM. These collected spores can be used as inoculum with rate ( 500 spores per plant).

\section{Bacterial Inoculum Preparation}

Azotobacter chroococcum and Azospirillum lipoferum were isolated from the rhizosphere of barley plant and Rhizobium leguminosarum isolated from nodules of faba bean located in Sahle El Tina, North Sinai. Rhizobium leguminosarum used from this study was grown on yeast-extract mannitol broth for $24 \mathrm{~h}$ at $28^{\circ} \mathrm{C}$ (Jordan, 1984). A. chroococcum was grown on modified Ashby's medium (Abd El-Malek and Ishac, 1968) for 5 days at $28 \pm 2^{\circ} \mathrm{C}$ and A. lipoferum was grown on Dobereiner media (Dobereiner et al., 1980), for 5 days at $28 \pm 2^{\circ} \mathrm{C}$. The active PGPR was inoculated in $250 \mathrm{ml}$ conical flasks that contained $100 \mathrm{ml}$ specific media then enriched in the same medium and incubated to reach $10^{8} \mathrm{cfu} / \mathrm{ml}$. The bacterial inocula were applied as a soil treatment at the rate of $30 \mathrm{ml}$ of bacterial suspension $\left(10^{8} \mathrm{cfu} / \mathrm{ml}\right)$ per plant and the mixture of them was applied as a soil treatment at the rate of $10 \mathrm{ml}$ for the three of them per plant.

\section{Evaluation of Bacterial Strains \\ 4.1. Nitrogen fixation ability}

Determination of nitrogen fixing activity in pure culture of Rhizobium leguminosarum, Azotobacter chroococcum and Azospirillum lipoferum was conducted. Bacterial isolates were grown on their specific media for three days, no inoculated media served as control. Afterwards, the concentration of nitrogen in each liquid culture was measured by digestion and subsequent measurement by the Kjeldahl method (Bremner and Mulvaney, 1982).

Nitrogenase activity was determined by acetylene reduction technique using gas chromatography (Hewlett Packard chromatography model HP $6890 \mathrm{GC}$ ) fitted with dual flame detector and $150 \mathrm{~cm} \times 0.4 \mathrm{~cm}$ diameter stainless still column fitted with propak x R100-120 mesh according to methods of Hardy et al. (1973) and Somasegaran and Hoben (1985). The results were presented as $n$. mole $\mathrm{C}_{2} \mathrm{H}_{4} / \mathrm{ml}$ culture $/ \mathrm{h}$.

\subsection{Phosphate solubilization}

Pikovskaya's medium (glucose $10 \mathrm{~g} / \mathrm{L}, \mathrm{Ca}_{3}\left(\mathrm{PO}_{4}\right)_{2} \quad 5 \mathrm{~g} / \mathrm{L}$, $\mathrm{MgSO}_{4} .7 \mathrm{H}_{2} \mathrm{O} \quad 0.1 \mathrm{~g} / \mathrm{L}, \mathrm{NaCl} 0.2 \mathrm{~g} / \mathrm{L},\left(\mathrm{NH}_{4}\right)_{2} \mathrm{SO}_{4} 0.5 \mathrm{~g} / \mathrm{L}, \mathrm{FeSO}_{4} .7 \mathrm{H}_{2} \mathrm{O}$

Egyptian J. Desert Res., 69, Special Issue, 131-150 (2019) 
$0.002 \mathrm{~g} / \mathrm{L}, \mathrm{KCl} 0.2 \mathrm{~g} / \mathrm{L}$, yeast extract $0.5 \mathrm{~g} / \mathrm{L}, \mathrm{MnS} \mathrm{O}_{4} 0.002 \mathrm{~g} / \mathrm{L}$, agar $20 \mathrm{~g} / \mathrm{L}$, $\mathrm{pH} 7.0$ ) with $2.4 \mathrm{mg} / \mathrm{ml}$ bromothymol blue was used for phosphate solubilization. The media inoculated with the isolates were incubated for 48 $\mathrm{h}$ and observed for yellow color change as positive for solubilizing phosphate (Pikovskaya, 1948).

\subsection{Indole acetic Acid (IAA) production}

Indole acetic acid (IAA) production was estimated in all bacterial cultures by using spectrophotometer as described by Ehmann (1977). For this purpose, $50 \mathrm{ml}$ of each specific medium supplemented with $1 \mathrm{~g} / \mathrm{L}$ of $\mathrm{L}$ tryptophan as a precursor of IAA was inoculated with selected bacterial isolate, incubated at $30^{\circ} \mathrm{C}$ for $48 \mathrm{~h}$ and centrifuged at $6000 \mathrm{rpm}$ for $30 \mathrm{~min}$ to collect supernatant. Then, supernatant and Salkowski reagent $(2.0 \mathrm{ml}$ of $0.5 \mathrm{M} \mathrm{FeCl}_{3}+98.0 \mathrm{ml}$ of $35 \% \mathrm{HClO}_{4}$ ) were mixed in test tubes at the ratio of 1: 2 and the contents were allowed to stand for half an hour for color development. The intensity of color was measured at $520 \mathrm{~nm}$ by using spectrophotometer and compared with standard curve of IAA.

\section{Greenhouse Experiment}

Greenhouse experiment was conducted to study the effect of mycorrhizal fungi (Glomus mosseae) alone or as mixture with some plant growth-promoting bacteria (PGPB) (Azospirillum lipoferum, Azotobacter chroococcum and Rhizobium leguminosarum on nematode population of Meloidogyne incognita. One-month old tomato seedlings (Solanum lycopersicum cv. super strain P) with uniform size were transplanted singly in $15 \mathrm{~cm}$ clay pots filled with mixture of sterilized clay and sand soil (1:2, $\mathrm{v} / \mathrm{v})$. After ten days, the tomato plants were treated with mycorrhizal fungi (Glomus mosseae) and some PGPB; Azospirillum lipoferum, Azotobacter chroococcum and Rhizobia spp. After two weeks, nematode inoculation was added with 2000 newly hatched second stage larvae of Meloidogyne incognita by making 3 holes at different depths $(2-3 \mathrm{~cm})$ around the roots and immediately after inoculation the roots were covered with soil. Then the previously microbial inoculants were re-added at the same rate, after 15 days of infestation. The experiment was divided to eleven treatments. Every treatment consists of three replicates. The treatments were as follows:

1. AM fungi

2. AM fungi + Azospirillum lipoferum

3. AM fungi + Azotobacter chroorcoccum

4. AM fungi + Rizobium leguminosarum

5. AM fungi + Azospirillum lipoferum + Azotobacter chroococcum + Rizobium leguminosarum

6. Azospirillum lipoferum

7. Azotobacter chroococcum

8. Rizobium leguminosarum

Egyptian J. Desert Res., 69, Special Issue, 131-150 (2019) 
9. Control without nematode

10. Chemical control "oxamyl $24 \%$ EC" was applied at the rate of 0.03 $\mathrm{ml} /$ pot

11- Control with nematode

All treatments were arranged in a completely randomized design under greenhouse condition at temperature degree $35 \pm 2^{\circ} \mathrm{C}$. All plants received $1 \mathrm{~g}$ NPK (19-19-19) a slow release fertilizer at planting every two weeks. Pots were watered periodically every three days. The plants were harvested after 60 days from inoculation time.

\subsection{The reduction percentage in nematode enumeration and plant growth parameters determination}

Soil of each pot was processed for nematode extraction by sieving and Baerman-pan technique (Southey, 1970). A count of second stage juveniles (J2) in soil of each pot was determined by means of Hawksley counting slide and stereoscopic microscope. Also, average numbers of eggs/egg masses were determined by rinsing four randomizely selected egg masses per root system of each replicate in $1 \%$ sodium hypochlorite to release eggs from egg matrix. Then, the released eggs were suspended in water and counted under stereoscopic microscope. Collected juveniles were counted. Galls and egg-masses and their indices were rated. The reduction percentage in galls formation, egg-masses production, also female's numbers were counted and juveniles' number were calculated according to the following formula: (Control-Infected)/ Control) $\times 100$

The final population and nematode buildup were calculated for all treatments.

Final Population (F.P.) included number of juveniles in soil+ egg-masses+ females.

Rate of buildup $(\mathrm{PF} / \mathrm{PI})=$

Final nematode population PF/ Initial nematode population PI (Norton, 1978).

Plant growth response based on shoot length fresh and dry shoot weights as well as root fresh weight and length were determined and calculated for all treatments. At harvest, the following microbiological measurements were conducted:

\subsection{Fungal spore enumeration}

The Spores from lower sieve were then washed onto a 9 girded filter paper disc. The filter paper was transferred clean Petri dish lids and enumerated. AM fungal spore enumeration included both dead and viable spores, although every attempt was made to count only healthy-looking spores. Spores were recorded as representatives of AM fungal species present in $100 \mathrm{~g}$ of sample (Smith and Dickson, 1997). This was done using a dissecting microscope (Leica S4E).

Egyptian J. Desert Res., 69, Special Issue, 131-150 (2019) 


\subsection{Dehydrogenase activity}

Soil dehydrogenase activity ( $\mu \mathrm{g} \mathrm{TPF} / \mathrm{g}$ dry soil/24 h) was analyzed by the reduction of triphenyl tetrazolium chloride (TTC) to triphenyl formazan (TPF) as described by Friedel et al. (1994).

\section{Statistical Analysis}

Statistical analysis was carried out according to the procedure "Anova" recorded by Snedecor and Cochran (1980). Means of treatments were compared by Dancann's Multiple Range Test at 5\% level of probability. These steps were accomplished using SPSS Program version 16.

\section{RESULTS}

Through a greenhouse experiment, application of mycorrhizal fungi (Glomus mosseae) and some PGPB; Azospirillum lipoferum, Azotobacter chroococcum and Rhizobium leguminosarum alone and as mixed genera with arbascular mycorrhizae (AM) fungi on nematode population of Meloidogyne incognita, in compare with the nematicide oxamyl (24\% EC) as in table (1) showed that, all treatments significantly affected Meloidogyne sp. and could arrest its reproduction rate compared with control treatment, concerning reduction percentage of juveniles number, galls, females, egg-masses, eggs per egg-mass, the final population and nematode buildup were diminished that occurred with all treatments. So, a successfully gradual scale for the effectiveness of used application can be done as follows: mixed all PGPB with mycorrhizal fungi> Azospirillum lipoferum + mycorrhizal fungi $>$ Rizobium leguminosarum + mycorrhizal fungi $>$ Azotobacter chroococcum + mycorrhizal fungi $>$ Azospirillum $>$ Rhizobia spp $>$ mycorrhizal fungi> Azotobacter chroococcum. This scale was related with the final population reduction and nematode buildup when compared with untreated control

The highest reduction percentage of juveniles was obtained from mixed all PGPB with mycorrhizal fungi (86.88\%) and Azospirillum lipoferum + mycorrhizal fungi (80.6\%), while the lowest was obtained from Azotobacter chroococcum (57.2\%) and mycorrhizal fungi (56.35\%). Also, treatments of mixed PGPB with mycorrhizal fungi and Azospirillum lipoferum still gave the highest effect in galls and females reduction where they could increase this reduction until reaching $94.1 \%, 92.1 \%, 95.8 \%$ and 90.5\%, respectively. While, Azospirillum lipoferum and Azotobacter chroococcum recorded the lowest effect in galls $(72.3 \%$ and $67.4 \%$, respectively). While the lowest females' reduction percentages were registered by Rizobium leguminosarum (69.8\%) and Azotobacter chroococcum (56.4\%). Also, production of egg masses and inhabitation of 


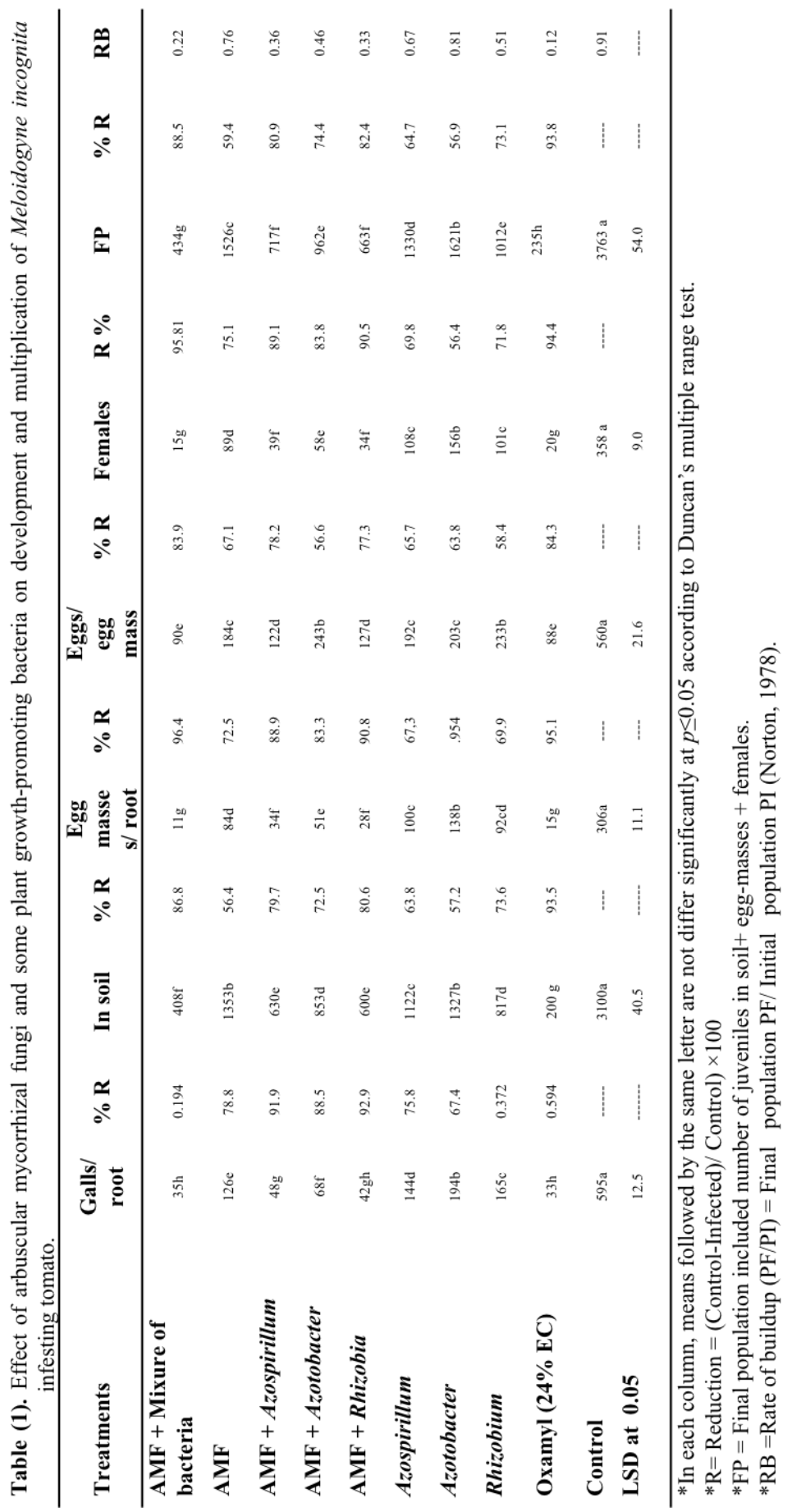

Egyptian J. Desert Res., 69, Special Issue, 131-150 (2019) 
egg production was more pronounced in treatments were adversely affected by the mixed PGPB with mycorrhizal fungi.

The effect of mycorrhizal fungi (Glomus mosseae) and some PGPB; Azospirillum lipoferum, Azotobacter chroococcum and Rhizobium leguminosarum alone and mixed genera of AM fungi on growth of tomato infected with Meloidogyne incognita.

In comparison with the nematicide oxamyl $(24 \%$ EC) recorded in table (2), all treatments succeeded in improving the plant growth parameters as compared to check with nematode. For instance, the treatment of mixed PGPB with mycorrhizal fungi gave the best result in increment the fresh, dry weight, shoot length and fruit weight with averages $109.8 \%, 98.7 \%, 62.0 \%$ and $440.0 \%$, followed by the treatment of Azospirillum lipoferum + mycorrhizal fungi (Glomus mosseae), which gave 84.0\%, 76.3\%, 48.9\%, $343 \%$, respectively, as compared with check treated with nematode. On the other hand, Rhizobium leguminosarum recorded less averages of $4.6 \%$, $13.2 \%, 2.6 \%$ and $77.0 \%$ in fresh, dry weight, the shoot length and fruit weight, respectively, followed by the treatment of Azotobacter chroococcum that recorded $4.6 \%, 13.2 \%, 21.8 \%$ and $67 \%$.

The growth rate of root lengths was recorded increasing at all treatments, which ranged between $51.7 \%$ and $11.9 \%$ and root weight, which ranged between $44.0 \%$ and $4.4 \%$ as compared with check treated with nematode. In general, all treatments of tested materials as well as oxamyl ( $24 \%$ EC) caused remarkable increase in the plant growth parameters.

Nitrogenase enzyme is considered as an indication of the ability of free-living bacteria to fix atmospheric nitrogen. According to data illustrated in table (3), both Azotobacter chroococcum and Azospirillum lipoferum recorded high nitrogenase activity $\left(77.40,81.539 \mathrm{n}\right.$. mole $\left.\mathrm{C}_{2} \mathrm{H}_{4} / \mathrm{ml} / \mathrm{h}\right)$, while Rhizobium leguminosaru fixed nitrogen in nodules. Azotobacter and Azospirillum isolates exhibited nitrogenase activities ranged from 15.4 to $96.1 \mathrm{n}$. mole $\mathrm{C}_{2} \mathrm{H}_{4} / \mathrm{ml} / \mathrm{h}$. All strains were subjected for dissolving phosphate in growing medium, and recorded 32, 27 and 29 ppm, respectively. Microorganisms belonging to the genera Pseudomonas, Bacillus, Rhizobium, Azotobacter and Azospirillum spp. frequently have the ability to solubilize phosphorus. On the other hand, Azospirillum lipoferum produced the highest amount of IAA $(160.31 \mu \mathrm{g} / \mathrm{ml})$, followed by isolates Rizobium leguminosarum and Azotobacter chroococcum, which gave 140.21 and $90.25 \mu \mathrm{g} / \mathrm{ml}$ ) respectively. Nitrogen fixers achieved different activities of IAA ranging from 31 to $168 \mu \mathrm{g} / \mathrm{ml}$ and gibberellins from 2.8 to $29.4 \mu \mathrm{g} / \mathrm{ml}$. It was clear from table (4) that, the count of spores was increased by inoculation with VAM. The inoculation with PGPR mixture + $\mathrm{AMF}+\mathrm{N}$ recorded the highest value (384 spores/g dry soil), followed by AMF with single bacterial inoculation while $\mathrm{AMF}+\mathrm{N}$ recorded the least one (208 spores/g dry soil).

Egyptian J. Desert Res., 69, Special Issue, 131-150 (2019) 


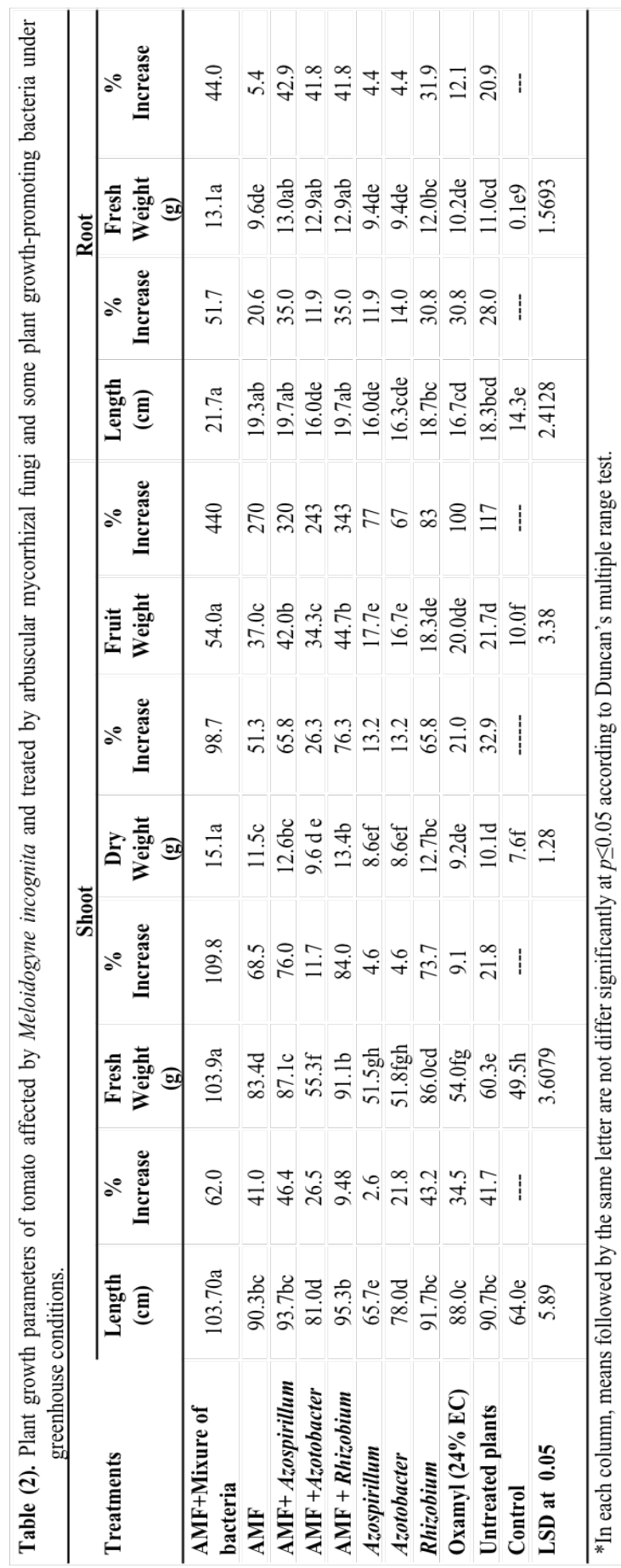

Egyptian J. Desert Res., 69, Special Issue, 131-150 (2019) 
The value of dehydrogenase activity was increased by inoculation with mixed PGPR + VAM + nematode, it recorded $390 \mu \mathrm{g}$ TPF/g dry soil/24 $\mathrm{h}$, followed by single inoculation with AMF, compared to control (untreated plants). Inoculation with Azospirillum gave the highest result among the other bacterial treatment and plant with active nematode gave the least result.

Table (3). Count of vesicular arbuscular mycorrhiza (VAM) and dehydrogenase activity in the rhizosphere of tomato plant at the harvest.

\begin{tabular}{l|c|c}
\hline \multicolumn{1}{c|}{ Treatment } & $\begin{array}{c}\text { VAM count } \\
\text { (Spores /200 g dry } \\
\text { soil) }\end{array}$ & $\begin{array}{c}\text { Dehaydrogenase } \\
(\boldsymbol{\mu g} \text { TPF/g dry } \\
\text { soil/24 h }\end{array}$ \\
\hline $\begin{array}{l}\text { AMF + Mixure of } \\
\text { bacteria }\end{array}$ & $384 \mathrm{~A}$ & $390 \mathrm{~A}$ \\
AMF & 208E & $237 \mathrm{~F}$ \\
AMF + Azospirillum & $288 \mathrm{~B}$ & $290 \mathrm{~B}$ \\
AMF+Azotobacter & $224 \mathrm{D}$ & $221 \mathrm{G}$ \\
AMF + Rhizobium & 240C & $257 \mathrm{D}$ \\
Azospirillum & $\mathrm{Nil}$ & $262 \mathrm{C}$ \\
Azotobacter & $\mathrm{Nil}$ & $243 \mathrm{E}$ \\
Rhizobium & $\mathrm{Nil}$ & $241 \mathrm{~F}$ \\
N + oxamyl (24\% EC) & $\mathrm{Nil}$ & $\mathrm{Nil}$ \\
Untreated plants & $\mathrm{Nil}$ & 173 \\
Control & $\mathrm{Nil}$ & $191 \mathrm{H}$ \\
LSD at 0.05 & 2.8881 & 3.0348 \\
\hline
\end{tabular}

*In each colum, means followed by the same letter are not differ significantly at $(p \leq 0.05)$ according to Duncan's multiple range test.

Table (4). Plant growth promoting traits of rhizobacterial strain.

\begin{tabular}{|c|c|c|c|}
\hline $\begin{array}{l}\text { Test } \\
\text { organisms }\end{array}$ & 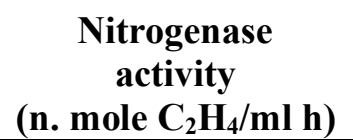 & $\begin{array}{c}\text { Phosphate } \\
\text { dissolving } \\
\text { activity (ppm) }\end{array}$ & $\underset{(\mu \mathrm{g} / \mathrm{ml})}{\mathbf{I A A}}$ \\
\hline $\begin{array}{l}\text { Azotobacter } \\
\text { chroococcum }\end{array}$ & 77.402 & 32 & 90.25 \\
\hline $\begin{array}{l}\text { Azospirillum } \\
\text { lipoferum }\end{array}$ & 81.534 & 27 & 160.31 \\
\hline $\begin{array}{l}\text { Rhizobium } \\
\text { leguminosarum }\end{array}$ & ----- & 29 & 140.21 \\
\hline
\end{tabular}

Egyptian J. Desert Res., 69, Special Issue, 131-150 (2019) 


\section{DISCUSSION}

PGPR and AM fungi in tomato roots tested under greenhouse conditions had an effect on decreasing the final M. incognita population and the rate of nematode buildup. Physiological and biochemical changes caused by mycorrhizal fungi in the host plant generally reduce the severity of nematode population, that cause an inhibitory effect on nematode development through releasing organic acids, which are often accompanied with the release of other metabolites, mainly, phytohormones and lytic enzymes (Mukerji and Ciancio, 2007 and Akhtar and Siddiqui, 2008).

In addition, the increased phenolic compounds phytoalexins, lignin, phenols, sugars and amino acid phenylalanine and serine in mycorrhiza treated plants have been suggested to play an important role in the plant defense mechanism (Zhang et al., 2008). Also, PGPR strains Azotobacter chroococcum and Azospirillum brasilense inhibited egg hatching and killed juveniles by producing a wide variety of antibiotics, hydrolytic enzymes, organic compounds, HCN, phenol oxidation and protease (Insunza et al., 2002). Azotobacter chroococcum, Azospirillum brasilense and Rhizobium leguminosarum may also improve plant growth, nodulation parameters as well as chemical components by the production of biologically active substances of growth hormones (IAA, gibberellins and auxins) or by converting unavailable minerals and organic compounds into forms available to plants (Siddiqui and Mahmood, 1999 and Ashoub and Amara, 2010).

In addition, PGPR strains usually have been found to increase the root length and root biomass and this better developed root system may increases the mineral uptake in plants (Khalid et al., 2004; Siddiqui and Akhtar, 2007). The AM fungi and PGPR can stimulate each other and play a synergistic activity and function in improving plant growth and in reducing plant disease (Shreenivasa et al., 2007).

Reports about mycorrhiza and PGPR-induced resistance against plant-parasitic nematodes have been reviewed by Pinochet et al. (1996), Verhagen et al. (2004), Hol and Cook (2005), Timonen and Marschner (2006), Akhtar and Siddiqu (2008) and Pieterse et al. (2009).

Arbuscular mycorrhizal fungi are known to be able to increase the uptake of water and mineral nutrients for their host plant, such as phosphate and nitrogen (Parniske, 2008 and Baum et al., 2015), but probably also micro-elements such as zinc (Smith and Smith, 2011a, b). In return, they receive photosynthetic carbon from their host (Gianinazzi et al., 2010). Similar to the protection of the plant by AMF against various abiotic stress factors such as drought, cold or heavy metal toxicity (Singh et al., 2011).

Egyptian J. Desert Res., 69, Special Issue, 131-150 (2019) 
AMF could also compensate for damage caused by pathogens. Although higher uptake of phosphate has been proposed as a mechanism for the AMF-mediated biocontrol, addition of phosphate to non-mycorrhizal plants did not result in a similar reduction of pathogen infection (Bodker et al., 1998). Fritz et al. (2006) reported that there is thus not always a positive correlation between increased phosphate uptake and plant growth promotion in mycorrhizal plants, as in some cases plant growth suppression resulted as a consequence of AMF colonization. Dehydrogenase is an oxidoreductase, which only present in viable cells and is maker of soil health and is a valid indicator of changes in total microbial load in soil management (Roldán et al., 2004).

Even when phosphate transport from the AMF to the host plant was taking place (Smith and Smith, 2011a), the results confirm the suitability of AMF inoculation to improve plant health of tomato infected with root knot nematode. The management of these symbionts represents a suitable biocontrol strategy against root knot nematode in this crop. The supplementary addition of other beneficial microorganisms such as PGPR can also be considered as a method of enhancing the AMF effect. However, due to the high specificity involved in these types of interactions, a previous screening to select the best microbe-host plant combination should be done in order to optimize results (Attia, 1999).

The best-studied mechanisms of bacterial plant growth promotion include providing plants with resources/nutrients that they lack such as fixed nitrogen, iron and phosphorus. Many agricultural soils lack a sufficient amount of one or more of these compounds, so that plant growth is suboptimal. To obviate this problem and obtain higher plant yields, farmers have become increasingly dependent on chemical sources of nitrogen and phosphorus Besides being costly.

The production of chemical fertilizers depletes nonrenewable resources, the oil and natural gas are used to produce these fertilizers, and poses human and environmental hazards.

It would obviously be advantageous if efficient biological means of providing nitrogen and phosphorus to plants could be used to substitute for at least a portion of the chemical nitrogen and phosphorus that is currently used. In addition to Rhizobia spp., a number of free-living bacteria, for example Azospirillum spp., are also able to fix nitrogen and provide it to plants (Bashan and Levanony, 1990).

However, it is generally believed that free-living bacteria provide only a small amount of what the fixed nitrogen that the bacteriallyassociated host plant requires (James and Olivares, 1997). In this study, AMF inoculation increased phosphate-solubilizing (Rodríguez and Fraga, 1999). The inoculation process has a positive effect on the activity and abundance of microbial community in the rhizosphere, which appeared as 
remarkable increase in the dehydrogenase activity of treated plant compared to control. Measurement of dehydrogenase activity by indigenous microorganisms in soil has the potential to serve as a useful indicator of the microbial activity to determine the relative effectiveness of the plant rhizosphere in soils (Mathew and Obbard, 2001 and Omer, 2017).

That cause an inhibitory effect on nematode development through releasing organic acids, which are often accompanied with the release of other metabolites, mainly phytohormones and lytic enzymes (Mukerji and Ciancio, 2007 and Akhtar and Siddiqui, 2008). In addition, the increased phenolic compounds phytoalexins, lignin, phenols, sugars and amino acid phenylalanine and serine in mycorrhiza treated plants have been suggested to play an important role in the plant defense mechanism (Zhang et al., 2008). Also, PGPR strains; Azotobacter chroococcum and Azospirillum brasilense inhibited egg hatching and killed juveniles by producing wide variety of antibiotics, hydrolytic enzymes, organic compounds, HCN, phenol oxidation and protease (Insunza and Eriksson, 2002).

\section{CONCLUSION}

Meloidogyne incognita on tomato can be controlled in order to improve growth characters and chemical components of infected plants by using some PGPB; Azospirillum lipoferum, Azotobacter chroococcum and Rhizobia sp. alone and as mixed genera with AM fungi.

\section{REFERENCES}

Abd El-Malek, Y. and Y.Z. Ishac (1968). Evaluation methods used in counting Azotobacter. J. Appl. Bact., 331: 269-275.

Akhtar MS and Z.A. Siddiqui (2008). Arbuscular mycorrhizal fungi as potential bioprotectants against plant pathogens. In: "Mycorrhizae Sustainable Agriculture and Forestry" (Siddiqui, Z.A.; M.S. Akhtar and K. Futai eds.). Springer Science + Business Media, pp. 61-97.

Ashoub, A.H. and M.T. Amara (2010). Biocontrol activity of some bacterial genera against root-knot nematode, Meloidogyne incognita. J. American Sci., 6: 321-328.

Attia, M. (1999). The efficiency improvements of mineral fertilizers used and maize yield by arbuscular mycorrhizal fungus and plant growthpromoting rhizobacteria, Ann. Agr. Sci., 44: 41-53.

Azcón, R. (1989). Selective interactions between free-living rhizospheric bacteria and vesicular-arbuscular mycorrhizal fungi, Soil Biol. Biochem., 21: 639-644.

Egyptian J. Desert Res., 69, Special Issue, 131-150 (2019) 
Barea, J.M. (2000). Rhizosphere and Mycorrhiza of Field Crops. In: "Biological Resource Management Connecting Science and Policy". Springer, Berlin, Heidelberg, pp. 81-92.

Baum, C., W. El-Tohamy and N. Gruda (2015). Increasing the productivity and product quality of vegetable crops using arbuscular mycorrhizal fungi: a review. Sci. Hortic. (Amsterdam), 187: 131-141.

Bartlem, D.G., M.G.K. Jones and U.Z. Hammes (2014). Vascularization and nutrient delivery at root-knot nematode feeding sites in host roots. J. Exp. Bot., 65: 1789-1798.

Bashan, Y. and H. Levanony (1990). Current status of Azospirillum inoculation technology: Azospirillum as a challenge for agriculture. Canadian Journal of Microbiology, 36: 591-608.

Bhattacharya, P.N. and D.K. Jha (2012). Plant growth-promoting rhizobacteria (PGPR): emergence in agriculture. World J. Microbiol. Biotechnol., 28: 1327-1350.

Bodker, L., R. Kjoller and S. Rosendahl (1998). Effect of phosphorus and the arbuscular mycorrhizal fungus Glomus intraradices on disease severity of root rot of peas (Pisum sativum) caused by Aphanomyces euteiches. Mycorrhiza, 8: 169-174.

Bremner, J.M. and C.S. Mulvaney (1982). In: "Nitrogen" (Page, A.L., R.H. Miller and D.R. Keeney eds.). Methods of Soil Analysis. Part 2, Chemical and Microbiological Properties. Agronomy 9, Soc. Agron., Madison, Wisconsin, pp. 595-624.

Dobereiner, J. and V.L.D. Baldani, Ann. Acad. Brasil. De cienc, Cited from Dobereiner, J. and H. De-polli (1980). Nitrogen fixation. Proceedings of the Phytochemical Society of Europe Symposium Series No. 18.

Duponnois, R. and C. Plenchette (2003). A mycorrhiza helper bacterium enhances ectomycorrhizal and endomycorrhizal symbiosis of Australian Acacia species. Mycorrhiza, 13: 85-91.

Ehmann, A. (1977). The Van Urk-Salkowski reagent-a sensitive and specific chromogenic reagent for silica gel thin-layer chromatographic detection and identification of indole derivatives. Journal of Chromatography, 132: 267-276.

Ferraz, L. and D. Brown (2002). An Introduction to Nematodes: Plant Nematology. Pensoft Series Parasitologica, 3, Sofia.

Friedel, J.K., K. Molter and W.R. Fischer (1994). Comparison and improvement of methods for determining soil dehydrogenase activity using triphenyl chloride and iodonitrotetrazolium chloride. Biol. Fertil. Soils, 18: 291-296.

Fritz, M., I. Jakobsen, M.F. Lyngkjaer, H. Thordal-Christensen and J. PonsKühnemann (2006). Arbuscular mycorrhiza reduces susceptibility of tomato to Alternaria solani. Mycorrhiza, 16: 413-419.

Egyptian J. Desert Res., 69, Special Issue, 131-150 (2019) 
Gianinazzi, S., A. Gollotte, M.N. Binet, D. van Tuinen, D. Redecker and D. Wipf (2010). Agroecology: the key role of arbuscular mycorrhizas in ecosystem services. Mycorrhiza, 20: 519-30.

Gerdemann, J.W. and T.H. Nicolson (1963). Spores of mycorrhizal Endogone species extracted from soil by wet sieving and decanting. Trans. Br. Mycol. Soc., 46: 235-244.

Giovannucci, E. (1999). Tomatoes, tomato-based products, lycopene and cancer: review of the epidemiological literature. Journal of the National Cancer Institute, 9: 317-331.

Hardy, R., R.C. Burns and R.D. Holsten (1973). Applications of the acetylene-ethylene assay for measurement of nitrogen fixation. Soil Biology and Biochemistry, 5 (1): 47-81.

Harrier, L.A. and C.A. Watson (2004). The potential role of arbuscular mycorrhizal (AM) fungi in the bioprotection of plants against soilborne pathogens in organic and/or other sustainable farming systems. Pest Manag. Sci., 60: 149-57.

Hol, W.H.G. and R. Cook (2005). An overview of arbuscular mycorrhizal fungi-nematode interactions. Basic Appl. Ecol., 6: 489-503.

Insunza, V., S. Alstrom and K.B. Eriksson (2002). Root bacteria from nematicidal plants and their biocontrol potential against trichodorid nematodes in potato. Plant Soil, 241: 271-278.

James, E.K. and F.L. Olivares (1997). Infection and colonization of sugar cane and other graminaceous plants by endophytic diazotrophs. Critical Reviews in Plant Sciences, 17 (1): 77-119.

Jordan, D.C. (1984). Genus I Rhizobium Frank 1889, 3AL. In: "Bergey's Manual of Systematic Bbacteriology", Vol. 1 (Krieg, N.R. and J.G. Holt eds.). Williams and Wilkins, Baltimore, pp. 235-24

Jones, J.T., A. Haegeman, E.G.J. Danchin, H.S. Gaur, J. Helder and M.G.K. Jones (2013). Top 10 plant-parasitic nematodes in molecular plant pathology. Mol. Plant Pathol., 14: 946-961.

Jung, S.C., A. Martinez-Medina, J.A. Lopez-Raez and M.J. Pozo (2012). Mycorrhiza-induced resistance and priming of plant defenses. J. Chem. Ecol., 38: 651-664.

Khalid, A., M. Arshad and Z.A. Zahir (2004). Screening plant growthpromoting rhizobacteria for improving growth and yield of wheat. J. App Microbiol., 96: 473-480.

Kloepper, J.W. and C.J. Beauchamp (1992). A review of issues related to measuring colonization of plant roots by bacteria. Can. J. Microbiol., 38: 1219-1232.

Mathew, M. and J.P. Obbard (2001). Optimization of the dehydrogenase assay for measurement of indigenous microbial activity in beach sediments contaminated with petroleum. Biotechnol. Lett., 23: 227230 .

Egyptian J. Desert Res., 69, Special Issue, 131-150 (2019) 
Mukerji, K.G. and A. Ciancio (2007). Mycorrhizae: The Integrated Pest and Disease Management. In: "General Concepts in Integrated Pest and Disease Management" (Ciancio, A. and K.G. Mukerji eds.). Springer, Section 2, pp. 245-266.

Norton, D.C. (1978). Ecology of Plant Parasitic Nematodes. Jon Willeg and Sons. New York, $238 \mathrm{p}$.

Nicol, J.M., S.J. Turner, D.L. Coyne, L. Den Nijs, S. Hockland and Z.T. Maafi (2011). Current Nematode Threats to World Agriculture. In: "Genomics and Molecular Genetics of Plant-Nematode Interactions" (Jones, J.T., G. Gheysen and C. Fenoll eds.). Heidelberg, Germany, Springer, pp. 21-44.

Oka, Y. and T. Mizukubo (2009). Tomato culture filtrate stimulates hatching and activity of Meloidogyne incognita juveniles. Nematology, 11: 51-61.

Omer, A.M. (2017). Using diazotrophic endophytes in improving some cereal production under saline desert condition. Egyptian J. Desert Res., 67 (1): 207-226.

Parniske, M. (2008) Arbuscular mycorrhiza: the mother of plant root endosymbioses. Nature Rev. Microbiol., 6: 763-775.

Pieterse, C.M.J., A. Leon-Reyes, S. van der Ent and S.C.M. van Wees (2009). Networking by small-molecule hormones in plant immunity. Nature Chemical Biology, 5 (5): 308-316.

Pikovskaya, R.I. (1948). Mobilization of phosphorus in soil in connection with vital activities of some microbial species. Microbiology, 17: 362- 370.

Pinochet, J., C. Calvet, A. Camprubi and C. Fernandez (1996). Interactions between migratory endoparasitic nematodes and arbuscular mycorrhizal fungi in perennial crops: a review. Plant Soil, 185: 183190.

Pozo, M.J and C. Azcon-Aguilar (2007) Unravelling mycorrhiza induced resistance. Curr. Opin. Plant Biol., 10: 393-398.

Roldán, A., J.R. Salinas-García, M.M. Alguacil, G. Díazc and F. Caravaca (2004). Changes in soil microbial activity following conservation tillage practices in sorghum field under subtropical conditions. International Soil Conservation Organization Conference, Brisbane.

Rodríguez, H. and R. Fraga (1999). Phosphate solubilizing bacteria and their role in plant growth promotion. Journal of Biotechnology Advances, 17: 319-339.

Serfoji, P., S. Rajeshkumar and T. Selvaraj (2010). Management of rootknot nematode, Meloidogyne incognita on tomato cv. Pusa Ruby by using vermicompost, AM fungus, Glomus aggregatum and mycorrhiza helper bacterium, Bacillus coagulans. J. Agric. Technol., 6: 37-45.

Egyptian J. Desert Res., 69, Special Issue, 131-150 (2019) 
Shamseldin, A., M.H. El-Sheikh, H.S.A. Hassan and S.S. Kabeil (2010). Microbial bio-fertilization approaches to improve yield and quality of Washington Navel orange and reducing the survival of nematode in the soil. J. American Sci., 6: 264-271.

Shreenivasa, K.R, K. Krishnappa and N.G. Ravichandra (2007). Interaction effects of arbuscular mycorrhizal fungus Glomus fasciculatum and root-knot nematode, Meloidogyne incognita on growth and phosphorous uptake of tomato. Karnataka J. Agric. Sci., 20: 57-61.

Snedecor, G.W. and W.G. Cochran (1980). In: "Statistical Methods". Oxford \& J.BH Publishing Com., $7^{\text {th }}$ edition.

Somasegaran, P. and H.J. Hoben (1985). Methods in legume-rhizobium technology. NifTAL Project and MIRCEN. Department of Agronomy, $2^{\text {nd }}$ Soil Science Hawaii Institute Tropical Agriculture Human Research, University of Hawaii at Manoa, Honolulu, pp. 152.

Southey, J.F. (1970). Laboratory Methods for Work with Plant and Soil Nematodes. Ministry of Agriculture, Fisheries and Food. Technical Bulletin 2, H.M. Stationery Office London, 148 p.

Siddiqui, Z.A. and I. Mahmood (1999). Role of bacteria in the management of plant parasitic nematodes: a review. Bioresource Technol., 69: $167-179$.

Siddiqui, Z.A. and M.S. Akhtar (2007). Effects of AM fungi and organic fertilizers on the reproduction of the nematode Meloidogyne incognita and on the growth and water loss of tomato. Biol. Fert. Soil, 43: 603-609.

Siddiqui, Z.A. and K. Futai (2009). Biocontrol of Meloidogyne incognita on tomato using antagonistic fungi, plant-growth-promoting rhizobacteria and cattle manure. Pest Manag. Sci., 65 (9): 943-948.

Singh, L.P., S.S. Gill and N. Tuteja (2011). Unraveling the role of fungal symbionts in plant abiotic stress tolerance. Plant Signal. Behav., 6: 175-191.

Smith, S. and S. Dickson (1997). VA mycorrhizas: Basic research techniques. Cooperative Research Centre for Soil and Land Management, Glen Osmond,

Smith F.A. and S.E. Smith (2011a). What is the significance of the arbuscular mycorrhizal colonization of many economically important crop plants? Plant Soil, 348: 63-79.

Smith S.E. and F.A. Smith (2011b). Roles of arbuscular mycorrhizas in plant nutrition and growth: new paradigms from cellular to ecosystem scales. Ann. Rev. Plant Biol., 62: 227-250.

Smith, S.E., E. Facelli, S. Pope and F.A. Smith (2010). Plant performance in stressful environments: interpreting new and established knowledge of the roles of arbuscular mycorrhizas. Plant Soil, 326: 3-20.

Egyptian J. Desert Res., 69, Special Issue, 131-150 (2019) 
Talor, A.A., V.H. Dropkin and G.C. Martin (1955). Perinil pattern of root nematodes. Phtopathol., 45: 26-34.

Timonen, S. and P. Marschner (2006). Mycorrhizosphere Concept. In: "Soil Biology" (Mukerji, K.G., C. Manoharachary and J. Singh, eds.). Springer-Verlag, Berlin, Germany, pp. 155-172.

Veresoglou, S.D. and M.C. Rillig (2012). Suppression of fungal and nematode plant pathogens through arbuscular mycorrhizal fungi. Biol. Lett., 8: 214-217.

Verhagen, B.W., M. Glazebrook, J. Zhu, H.S. Chang, L.C. van Loon and C.M.J. Pieterse (2004). The transcriptome of rhizobacteria-induced systemic resistance in Arabidopsis. Molecular Plant-Microbe Interactions, 17 (8): 895-908.

Vos, C.M., A.N. Tesfahun, B. Panis, D. De Waele and A. Elsen (2012). Arbuscular mycorrhizal fungi induce systemic resistance in tomato against the sedentary nematode Meloidogyne incognita and the migratory nematode Pratylenchus penetrans. Appl. Soil Ecol., 61: $1-6$.

Wesemael W., N. Viaene and M. Moens (2011). Root-knot nematodes (Meloidogyne spp.) in Europe. Nematology, 13: 3-16.

Whipps, J.M. (2004). Prospects and limitations for mycorrhizas in biocontrol of root pathogens. Can. J. Bot., 1227: 1198-1227.

Zhang, L., J. Zhang, P. Christie and X. Li (2008). Pre-inoculation with arbuscular mycorrhizal fungi suppress root knot nematode (Meloidogyne incognita) on cucumber (Cucumis sativus). Biol. Fertil. Soils, 45: 205-211. 


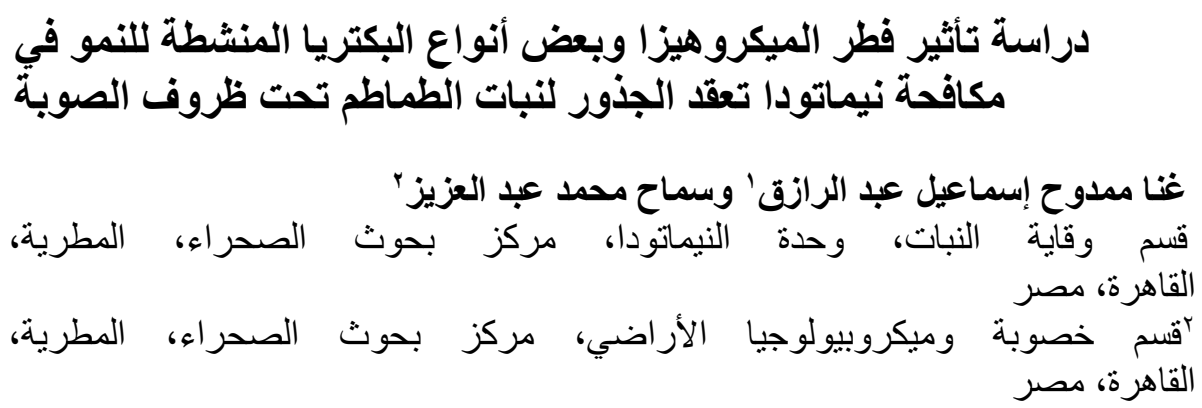

تم إجراء تجربة تحت ظروف الصوبة لتقييم تأثير بعض أنواع البكتيريا المشجعة لنمو النبات مثل Azotobacter chroorcoccum, Azospirillum lipoferum و بمفردهما أو خلطها مع فطريات الميكروهيزا Arbuscular mycorrhizal fungi لتحسين نمو نباتات الطماطم صنف سوبر ستريم بي وكذلك تنبيط نيماتودا تعقد الجذور

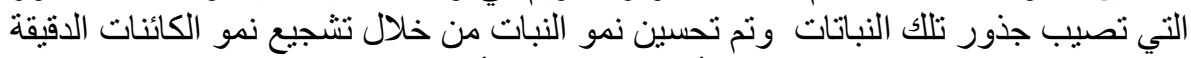

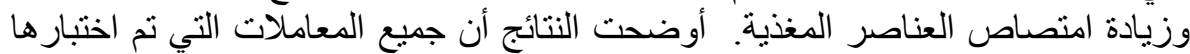

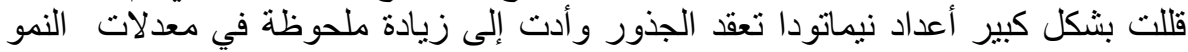

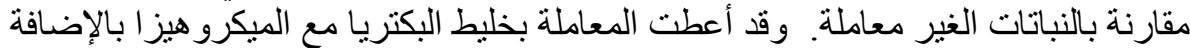

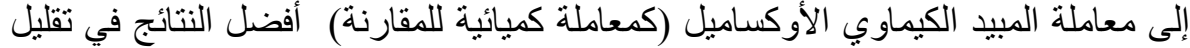
التعداد الكلي للنيماتودا في التربة و على الجذر وتقليل العقد الجذرية ومعدل التية التكاثر للنيماتودا.

Egyptian J. Desert Res., 69, Special Issue, 131-150 (2019) 